\title{
Gambaran Paparan Asap Rokok pada Ibu Hamil Berdasarkan Usia Kehamilan di Desa Cintamulya Kecamatan Jatinangor Kabupaten Sumedang
}

\author{
Sri Astuti ${ }^{1}$, Ari Indra Susanti ${ }^{1}$, Rica Elista ${ }^{2}$ \\ ${ }^{1}$ Departemen Ilmu Kesehatan Masyarakat, Fakultas Kedokteran Universitas Padjadajaran \\ ${ }^{2}$ Program Diploma Kebidanan Fakultas Kedokteran Universitas Padjadjaran
}

\begin{abstract}
Abstrak
Merokok selama kehamilan dapat berbahaya terhadap tumbuh kembang janin dalam kandungan. Ibu hamil yang merokok atau terpapar asap rokok akan dapat menimbulkan berbagai komplikasi seperti kelahiran sebelum waktunya (prematur), berat badan lahir kurang, mortalitas perinatal dan gangguan-gangguan perkembangan janin. Penelitian ini bertujuan untuk mengetahui gambaran paparan asap rokok pada ibu hamil berdasarkan usia kehamilan di Desa Cintamulya. Penelitian ini adalah penelitian deskriptif dengan pendekatan secara Cross Sectional. Pengambilan sampel dilakukan dengan teknik total sampling. Data diambil dari kuesioner yang dibagikan kepada $30 \mathrm{ibu}$ hamil di Desa Cintamulya. Hasil penelitian ini menunjukkan Ibu hamil yang terpapar asap rokok suami yang merokok di dalam rumah berdasarkan usia kehamilan paling besar didapatkan pada usia kehamilan 13-28 minggu sebanyak 9 orang. Paparan jumlah batang rokok per hari sebanyak $>10$ batang paling besar didapatkan pada usia kehamilan 13-28 minggu sebesar 5 orang. Ibu hamil yang terpapar asap rokok dalam setiap hari selama hamil selain di rumah paling besar didapatkan pada usia kehamilan 13-28 minggu sebesar 3 orang. Simpulan dari penelitian ini adalah ibu hamil yang lebih sering terpapar asap rokok dari suami maupun dari orang lain adalah ibu hamil dengan usia kehamilan 13-28 minggu.
\end{abstract}

Kata Kunci : Ibu hamil, Paparan asap rokok

\section{Exposure Of Cigarette Smoke To Pregnant Women Based On Pregnancy Age In Cintamulya Village, Jatinangor, Sumedang District}

\begin{abstract}
Smoking during pregnancy can be harmful to the growth and development of the fetus in the womb. Pregnant women who smoke or are exposed to cigarette smoke can lead to various complications such as preterm delivery (premature) birth weight less, perinatal mortality and fetal developmental disorders. This study aims to describe tobacco smoke exposure in pregnant women based on pregnancy in the village Cintamulya. This research is a descriptive cross sectional approach. Sampling was done by total sampling technique. Data taken from questionnaires distributed to 30 pregnant women in the village Cintamulya. The results of this study showed that pregnant women exposed to smoke husbands who smoke at home by age pregnancy is greatest obtained at 13-28 weeks of gestation were 9 people. Exposure to the number of cigarettes per day as much as $>10$ cigarettes most obtained at 13-28 weeks gestational age by 5 people. Pregnant women exposed to secondhand smoke every day during pregnancy than in the biggest house obtained at 13-28 weeks'gestation by 3 people. The conclusions of this study are pregnant women are more often exposed to smoke from her husband and from others are pregnant women with gestational age 13-28 weeks.
\end{abstract}

Keywords: Exposure to cigarette smoke, Pregnant women.

Korespondensi:

Sri Astuti, Per., Pend., M.Kes

Departemen Ilmu Kesehatan Masyarakat, Fakultas Kedokteran Universitas Padjadajaran

Jl. Prof. Dr. Eyckman No. 38 Bandung 40161

Mobile : 08122353282

Email : sriastuti29a@gmail.com 


\section{Pendahuluan}

Merokok selama kehamilan dapat berbahaya terhadaptumbuhkembang janin dalamkandungan. Menurut data World Health Organitation (WHO) pada tahun 2008 diperkirakan $45 \%$ wanita yang merokok, dan sebesar $27 \%$ wanita hamil yang merokok. Ibu hamil yang merokok di Amerika Serikat sebesar $23,5 \%$, dan sebesar $20 \%$ ibu hamil yang berhenti merokok selama kehamilan, pada ibu hamil yang merokok dapat menimbulkan komplikasi kehamilan, kesehatan reproduksi dan janin. ${ }^{1}$ Data dari Global Adult Tobacco Survey wanita yang terpapar asap rokok di rumah sebesar $78,4 \%{ }^{2}$

Asap rokok merupakan asap yang bercampur antara asap dan partikel. Asap ini terdiri dari 4000 senyawa kimia yang bercampur, termasuk didalamnya bahan beracun dan 69 diantaranya merupakan bahan penyebab kanker. ${ }^{3}$ Kebiasaan merokok bagi sebagian besar masyarakat di Indonesia masih dianggap sebagai perilaku yang wajar, dan merupakan bagian dari kehidupan sosial dan gaya hidup. Sebagian besar dari para perokok aktif mengabaikan risiko dan bahaya paparan asap rokok terhadap diri sendiri dan orang di sekitarnya. Di Indonesia, lebih dari 57\% dalam sebuah rumah tangga mempunyai sedikitnya satu orang perokok, dan hampir semua perokok $91,8 \%$ merokok di rumah. Prevalensi perokok pasif lakilaki di Indonesia 31,8\% dan perempuan $66 \%$. Rata-rata kokok yang dikonsumsi 1-10 batang per hari sebesar $51,7 \%$ dan rata-rata konsumsi rokok 11-20 batang per hari sebesar 42,6\%. ${ }^{4}$

Hasil data dari Indonesia wanita yang merokok sekitar 2,3\%, sedangkan pada ibu hamil sekitar $1,7 \%$, dari data ini telah membuktikan untuk menambah kemungkinan ibu hamil yang merokok akan dapat menimbulkan berbagai komplikasi seperti kelahiran sebelum waktunya (prematur), berat badan lahir kurang, mortalitas perinatal dan gangguan-gangguan perkembangan janin. Selain itu rokok juga dapat menyebabkan keguguran, gangguan tumbuh kembang anak, gangguan oksigen pada janin, dan gangguan pernapasan. Jika ibu merokok 10 batang per hari, maka kemungkinan anaknya akan menderita asma dua kali lebih besar. ${ }^{5}$

Akibat terpapar asap rokok pada saat hamil dapat menimbulkan efek buruk pada janin dalam kandungannya, pada wanita hamil yang merokok dapat berpotensi melahirkan bayi yang meninggal dibandingkan dengan wanita hamil yang tidak merokok, selain itu gizi ibu perokok biasanya lebih buruk dibandingkan yang tidak merokok karena kebiasaan merokok dapat mengurangi nafsu makan, selanjutnya nikotin merupakan zat vasokonstriktor yang berakibatkan metabolisme protein dalam tubuh janin yang sedang berkembang, dan detak jatung janin berdenyut lebih lambat yang akan menimbulkan gangguan sistem saraf janin. ${ }^{6}$

Menurut Undang-Undang Nomor 36 Tahun 2009 dan PP Nomor 19 tahun 2003 tentang larangan merokok di lingkungan seperti tempat umum, sarana kesehatan, tempat kerja, tempat proses belajar mengajar, karena kegiatan anak, tempat ibadah dan angkutan umum dinyatakan sebagai kawasan tanpa rokok. Sehingga pengamanan rokok bagi kesehatan khususnya pada ibu hamil yang berada di sekitar lingkungan tersebut dapat tepapar oleh asap rokok sebaiknya untuk menghindari asap rokok karena dengan asap rokok pun dapat mengakibatkan ibu hamil dan janin beresiko akan kesehatannya. ${ }^{7}$ Tidak merokok didalam rumah juga salah satu penerapan pola hidup bersih dan sehat di rumah tangga. ${ }^{8}$

Berdasarkan hasil survey awal yang dilakukan oleh peneliti data ibu hamil di Desa Cintamulya Kecamatan Jatinangor Kabupaten Sumedang pada tahun 2014 sebanyak 51 orang ibu hamil. Berdasarkan data hasil survey mawas diri yang dilakukan di desa Cintamulya pada tahun 2014 anggota keluarga ibu hamil yang merokok di dalam rumah adalah sebesar $69,1 \%$. Menurut studi pendahuluan yang dilakukan pada bulan April 2015 dari 10 ibu hamil di dapatkan 8 diantaranya mempunyai anggota keluarga yang merokok di dalam rumah.

Oleh karena itu peneliti tertarik untuk melakukan penelitian mengenai gambaran paparan asap rokok pada ibu hamil berdasarkan usia kehamilan di Desa Cintamulya.

\section{Metode}

Penelitian ini menggunakan metode penelitian deskriptif dengan pendekatan secara Cross Sectional. Populasi dalam penelitian ini adalah ibu hamil trimester 1, 2, dan 3 di Desa Cintamulya Kecamatan Jatinangor Kabupaten Sumedang yang berjumlah 30 orang. Waktu penelitian yaitu bulan April 2015 - Januari 2016. Teknik pengambilan sampel yang digunakan pada penelitian ini adalah teknik total sampling. Sampel pada penelitian ini seluruh populasi dalam penelitian yaitu semua ibu hamil di Desa Cintamulya yang berjumlah 30 orang. Variabel dalam penelitian ini adalah paparan asap rokok pada ibu hamil berdasarkan usia kehamilan. Data yang dikumpulkan adalah data primer tentang paparan asap rokok pada ibu hamil. Alat pengumpulan data menggunakan kuesioner. Cara pengumpulan data yaitu dengan membagikan kuesioner kepada seluruh ibu hamil 
Sri Astuti : Gambaran Paparan Asap Rokok Pada Ibu Hamil Berdasarkan Usia Kehamilan di Desa Cintamulya Kecamatan Jatinangor Kabupaten Sumedang

di desa Cintamulya dengan cara mengikuti setiap acara posyandu tiap RW dan mendatangi dari rumah ke rumah. Setelah semua data terkumpul, maka peneliti melakukan pengolahan data melalui beberapa tahap yaitu memeriksa ketepatan dan kelengkapan data. Data yang telah terkumpul dikoreksi ketepatan dan kelengkapannya, kemudian dimasukkan kedalam program komputer. Data disajikan dalam bentuk distribusi frekuensi. Analasis data yang digunakan pada penelitian ini adalah univariat. Analisis univariat dalam penelitian ini dilakukan untuk mengetahui dan mendapatkan hasil terhadap gambaran paparan asap rokok pada ibu hamil berdasarkan usia kehamilan.
Hasil

Dari tabel 1 dapat diketahui bahwa suami yang merokok di dalam rumah berdasarkan usia kehamilan yang paling besar didapatkan pada usia kehamilan 13-28 minggu sebanyak 9 orang. Suami responden merokok berada di luar rumahberdasarkan usia kehamilan yang paling besar didapatkan pada usia kehamilan 13-28 minggu sebanyak 8 orang.

Dari tabel 2 menunjukkan bahwa paparan jumlah batang rokok per hari $\geq 10$ batang yang paling besar didapatkan pada usia kehamilan 1328 minggu sebanyak 5 orang.

Dan dari tabel 3 menunjukkan bahwa ibu

Tabel 1 Distribusi Frekuensi Paparan Asap Rokok Suami Berdasarkan Usia Kehamilan

\begin{tabular}{lccc}
\hline & \multicolumn{3}{c}{ Paparan Asap Rokok Suami } \\
\cline { 2 - 4 } & \multirow{2}{*}{ Usia Kehamilan } & Merokok di dalam rumah & Merokok di luar rumah \\
\cline { 2 - 3 } & $\mathbf{f}$ & $\mathbf{f}$ \\
\hline $0-12$ & 3 & 0 \\
$13-28$ & 9 & 8 \\
$29-42$ & 4 & 4 \\
\hline Total & $\mathbf{1 6}$ & $\mathbf{1 2}$ \\
\hline
\end{tabular}

Tabel 2 Paparan Jumlah Batang Rokok per hari Berdasarkan Usia Kehamilan

\begin{tabular}{|c|c|c|}
\hline \multirow{3}{*}{ Usia Kehamilan } & \multicolumn{2}{|c|}{ Paparan Jumlah Batang Rokok per hari } \\
\hline & $<10$ Batang & $\geq 10$ Batang \\
\hline & f & $\mathbf{f}$ \\
\hline $0-12$ & 1 & 0 \\
\hline $13-28$ & 2 & 5 \\
\hline $29-42$ & 3 & 1 \\
\hline Total & 6 & 6 \\
\hline
\end{tabular}

Tabel 3 Distribusi Frekuensi Paparan Asap Rokok pada Ibu Hamil Selain di Rumah Berdasarkan Usia Kehamilan

\begin{tabular}{|c|c|c|}
\hline \multirow{3}{*}{ Usia Kehamilan } & \multicolumn{2}{|c|}{ Frekuensi Paparan Asap Rokok Selain di Rumah } \\
\hline & Terpapar setiap hari & Tidak terpapar setiap hari \\
\hline & f & f \\
\hline $0-12$ & 0 & 3 \\
\hline $13-28$ & 3 & 12 \\
\hline $29-42$ & 2 & 2 \\
\hline Total & 5 & 17 \\
\hline
\end{tabular}


hamil yang terpapar asap rokok setiap hari selama hamil selain di rumahpaling besar didapatkan pada usia kehamilan 13-28 minggu sebanyak 3 orang.

\section{Pembahasan}

Berdasarkan hasil penelitian yang dilalukan di Desa Cintamulya didapatkan bahwa suami yang merokok di dalam rumah berdasarkan usia kehamilan yang paling besar didapatkan pada ibu dengan usia kehamilan 13-28 minggu sebesar $56,25 \%$. Suami responden merokok berada di luar rumah berdasarkan usia kehamilan yang paling besar didapatkan pada usia kehamilan 13-28 minggu sebesar $66,67 \%$. kehamilan $13-28$ minggu sebesar $66,67 \%$.

Paparan asap rokok merupakan paparan asap yang dihirup oleh seseorang yang bukan perokok (perokok pasif). Asap rokok lebih berbahaya terhadap perokok pasif daripada perokok aktif.

Paparan asap rokok yang ibu hamil hirup selama di rumah berasal dari suami ibu hamil yang berstatus sebagai perokok aktif. Asap rokok yang dihembuskan oleh perokok aktif dan terhirup oleh perokok pasif, lima kali lebih banyak mengandung karbon monoksida, empat kali lebih banyak mengandung tar dan nikotin. ${ }^{12}$

Wanita yang terpapar asap rokok cenderung lebih sering mengalami gangguan pada kehamilannya karena kandungan zat kimia pada perokok pasif lebih tinggi dibandingkan perokok aktif. Merokok di ruangan tertutup akan meningkatkan konsentrasi partikel asap rokok sebagian diantaranya toksik (racun). ${ }^{13}$ Menurut penelitian asap rokok dapat tertinggal lama dalam suatu ruangan, toksin yang terkandung dari asap rokok melekat pada pakaian, tertinggal dalam ruangan, pintu dan perabotan yang ada di sekitarnya selama beberapa minggu dan bulan setelah digunakan untuk merokok. Pada saat pintu dan jendela dibuka atau kipas angin dinyalakan maka toksin akan kembali ke udara di sekitarnya. Kondisi ini menyebabkan wanita dengan suami perokok atau tinggal di lingkungan yang terdapat banyak perokok akan menjadi perokok pasif. ${ }^{14}$ Kehadiran perokok menyebabkan repirable particulates menjadi 3 hingga 12 kali lebih tinggi di dalam ruangan daripada di luar ruangan. ${ }^{13}$

Pada kehamilan khususnya pada trimester kedua terjadi proses penyempurnaan organ janin yang ada di dalam kandungan, jika gas-gas berbahaya dalam rokok dihirup oleh ibu hamil dan beredar ke pembuluh darah dapat menyebabkan pertumbuhan janin di dalam kandungan menjadi terganggu. Bahkan, hal ini dapat menyebabkan terjadinya mutasi gen di dalam tubuh ibu hamil sehingga menimbulkan kelainan kongenital pada bayi. 15

Jadi dalam penelitian ini seorang suami yang merokok di dalam rumah cenderung meningkatkan risiko terpaparnya asap rokok oleh ibu hamil, terutama pada tirmester 2, masa dimana terjadinya proses penyempurnaan organ sehingga jika terpapar asap rokok dapat mengakibatkan gangguan pada kehamilannya.

Pada penelitian ini usia kehamilan 13-28 minggu menunjukkan $83,33 \%$ terpapar dengan jumlah $\geq 10$ batang per hari. Perokok aktif dapat digolongkan menjadi dua bagian, yaitu perokok ringan dan perokok berat. Perokok ringan adalah perokok yang menghisap $<10$ batang per hari dan perokok berat adalah orang yang menghisap rokok $\geq 10$ batang per hari. ${ }^{9}$ Jika ibu hamil merokok atau terpapar asap rokok $\geq 10$ batang per hari, maka kemungkinan anaknya setelah lahir akan menderita asma dua kali lebih besar. ${ }^{10}$

Besarnya pengaruh paparan asap rokok pada ibu hamil sebagai penyebab terjadinya bayi berat lahir rendah. Penelitian menyebutkan bila ibu hamil terpapar asap rokok dari suami yang mengkonsumsi rokok antar 11-20 batang setiap hari berisiko 4,06 kali menyebabkan terjadinya bayi berat lahir rendah dibandingkan dengan tidak sama sekali menghisap rokok, bahkan meningkat 17,62 kali lebih berisiko bila terpapar asap rokok dari suami yang mengkonsumsi rokok $>20$ batang setiap harinya. Semakin banyak jumlah paparan asap rokok dari batang rokok yang di hisap maka semakin tinggi pula risiko ibu melahirkan bayi berat lahir rendah. ${ }^{16}$

Tidak dapat dihindari ketika paparan asap rokok terjadi pada saat ibu hamil sedang beraktifitas diluar rumah seperti pada hasil penelitian didapatkan bahwadi Desa Cintamulya frekuensi paparan asap rokok selain di rumah yaitu setiap hari sebesar $22,7 \%$.

Menjadi perokok pasif merupakan hal yang berbahaya karena racun rokok terbesar dihasilkan oleh asap yang mengepul dari ujung rokok yang tak dihisap. Bila ibu hamil yang berada dekat dengan suami atau keluarga bahkan orang lain yang sedang merokok setiap hari (perokok aktif), maka semakin berisiko mengalami gangguan kesehatan, terutama penyakit yang berhubungan dengan kehamilan. Racun rokok dalam tubuh perokok aktif terfilter melalui ujung rokok yang dihisap, hal ini sangat berbahaya terutama pada kondisi seorang ibu yang sedang hamil. Dampak dari terpaparnya asap rokok pada saat hamil ialah bayi lahir dengan berat lahir rendah, kelahiran prematur, ibu yang terpapar asap rokok selama kehamilan memiliki peluang lebih besar melahirkan bayi berat lahir rendah karena kandungan karbon monoksida dalam 
rokok yang dapat mengganggu kerja hemoglobin dalam mengikat oksigen yang diedarkan ke seluruh tubuh, sehingga janin dalam kandungan mengalami kekurangan oksigen dan nutrisi, memperparah asma dan alergi pada bayi juga sindrom kematian bayi mendadak. ${ }^{10}$

Berdasarkan penelitian didapatkan 4000 senyawa kimia berbahaya yang terdapat pada asap tembakau ini diantaranya adalah nikotin, tar, sianida, benzene, cadmium, metanol, amonia dan arsenik. Apabila penggunaan rokok yang banyak dan konsentrasi asap rokok yang tinggi mengakibatkan kandungan yang berbahaya berkembang menjadi lebih banyak dua kali lipat. Seseorang yang terpapar asap rokok setiap hari akan meningkatkan konsentrasi asap rokok semakin tinggi dalam tubuh, ibu hamil yang terpapar asap rokok setiap hari akan meningkatkan risiko dua kali lipat bahaya pada kehamilannya. Pemaparan jangka panjang pada perokok pasif dapat menyebabkan perkembangan arteoskelosis atau penyempitan pembuluh darah. ${ }^{11}$

Berdasarkan pedoman perilaku hidup bersih dan sehat yang telah ditetapkan pada poin ke10 dalam upaya memberdayakan anggota rumah tangga agar tahu, mau dan mampu melaksanakan perilaku hidup bersih dan sehat serta berperan aktif dalam gerakan kesehatan di masyarakat, pemerintah menegaskan pada masyarakat agar tidak merokok di dalam rumah. ${ }^{8}$

Pada Peraturan Daerah Kota Bandung Nomor 11 Tahun 2005 tentang penyelenggaraan ketertiban, kebersihan dan keindahan. Telah ditetapkan larangan merokok di tempat umum, sarana kesehatan, tempat kerja, dan tempat yang secara spesifik sebagai tempat proses belajar mengajar, arena kegiatan anak, tempat ibadah dan angkutan umum, maka dari itu akan dikenakan pembebanan biaya paksaan penegakan hukum sebesar Rp. 5.000.000,00 (lima juta rupiah), dan/atau sanksi administrasi berupa penahanan untuk sementara waktu, Kartu Tanda Penduduk, atau Kartu Identitas Kependudukan lainnya, dan/ atau pengumuman di media masa. ${ }^{17}$ Namun, sanksi yang di tetapkan masih belum di terapkan sehingga belum memberi efek jera bagi perokok, melihat masih banyak orang yang merokok di tempat umum, sedangkan di tempat umum terdapat banyak orang diantaranya ibu hamil yang menyebabkan kemungkinan terpapar asap rokok meningka. Jadi dalam penelitian ini kemungkinan ibu hamil terpapar asap rokok selain di rumah meningkat pada saat ibu melakukan aktifitas di luar rumah setiap hari terutama pada ibu hamil trimester kedua.

Simpulan dari penelitian ini adalahIbu hamil yang terpapar asap rokok suami yang merokok di dalam rumah berdasarkan usia kehamilan paling besar didapatkan pada usia kehamilan 13-28 minggu sebesar 56,25\%, paparan jumlah batang rokok per hari $\geq 10$ batang paling besar didapatkan pada usia kehamilan 13-28 minggu sebesar $83,33 \%$, dan ibu hamil yang terpapar asap rokok dalamsetiap hari selama hamil selain di rumah paling besar didapatkan pada usia kehamilan 13-28 minggu sebesar 60\%. Jika terpapar asap rokok pada usia kehamilan 1328 minggu akan meningkatkan risiko gangguan pada kehamilan terutama gangguan pertumbuhan dan perkembangan janin.

Saran untuk penelitian ini adalah bidan desa selaku petugas kesehatan agar mampu meningkatkan kesadaran masyarakat untuk berperan serta dalam memberikan edukasi dan juga motivasi yaitu mampu memberikan pengetahuan kepada masyarakat terutama ibu hamil terhadap bahaya paparan asap rokok aktif maupun pasif dengan cara memberikan penyuluhan bahaya merokok bagi perokok dan keluarga, penempelan sticker bahaya rokok untuk kesehatan di setiap rumah maupun lingkungan sekitar, karena masih banyak ibu hamil yang berstatus sebagai perokok pasif karena masih terpapar asap rokok dari orang lain. Bekerja sama dengan kader, aparat desa untuk mewujudkan Perilaku Hidup Bersih dan Sehat (PHBS) terutama tidak merokok di dalam rumah, di tempat umum, sarana kesehatan, tempat kerja, dan tempat yang secara spesifik sebagai tempat proses belajar mengajar, arena kegiatan anak, tempat ibadah dan angkutan umum

Dalam penelitian ini terdapat keterbatasan, yaitu pada variabel paparan asap rokok pada ibu hamil dalam penelitian ini menggunakan instrumen penelitian berupa kuesioner, sehingga rentan terjadi bias recall. Hal ini akan lebih baik apabila dilakukan pengambilan data dengan lembar observasi sesuai dengan pengambilan data.

\section{Daftar Pustaka}

1. Sinclair C. Buku saku kebidanan. Jakarta: EGC; 2009.

2. WHO. WHO Report On The Global Tobacco Epidemic. Warning about the dangers of tobacco;2011.

3. Kemenkes RI. Aliansi Bupati/Walikota Dalam Pengendalian Masalah Kesehatan Akibat Tembakau Dan Penyakit Tidak Menular. Buletin Jendela Data dan Informasi Kesehatan. Vol 2: Semester 2; 2012.

4. RISKESDAS. Hasil riset kesehatan dasar. Jakarta: Badan Penelitian dan Pengembangan Kesehatan Depkes RI; 2013.

5. BBLR (Bayi Berat Badan Rendah). 
Makasar:Universitas Hassanudin; 2011.

6. Aditama, T. Rokok dan Kesehatan. Jakarta: Universitas Indonesia (UI-Press); 2011.

7. Dinas Kesehatan Bogor. Bahaya Rokok Bagi Kesehatan Manusia. Bogor; 2011.

8. Dinas Kesehatan RI. Panduan Pembinaan dan Penilaian PHBS di Rumah Tangga; 2009.

9. Nindriani, Yuli. Hubungan Kebiasaan Merokok dan Olahraga Dengan Kadar Kolesterol Total Pada Polisi Lalu Lintas. Jawa Timur : ProgramStudi Epidemiologi dan Penyakit Tropik Fakultas Ilmu Kesehatan Universitas Siliwangi;2013.

10. Amiruddin, Ridwan. Status Gizi Ibu Hamil, Rokok, dan Efeknya.Makasar: Universitas Hassanudin; 2007.

11. Ronald, S. Gejala Penyakit dan Pencegahannya. Bandung: Yrama Wiidya; 2008.
12. Simpson.Tembakau Ancaman Global. Jakarta: PT. Elex Media Komputindo; 2010.

13. Husaini, Aiman.Tobat Merokok.Bandung: Mizan Medika Utama; 2007.

14. Mostafa. Dilema of Women's Passive Smoking. Annals of Thoracic Medicine. Vol 6.Issue 2. Page 55-56;2011.

15. Proverawati, A. Berat Badan Lahir Rendah. Yogyakarta: Nuha Medika; 2012.

16. Khattar, Divya., Awasthi, S., Dav, V.Residential Environment Tobacco Smoke Exposure During Pregnancy and Low Birth Weight of Neonatus Case Control Study in a Public Hospital in Lucknow, India.India: Departemen of Pedriatrics and Obstetrics and Gynecology; 2011.

17. Peraturan Daerah Kota Bandung No. 11 Tahun 2005 Tentang Penyelenggaraan Ketertiban, Kebersihan dan Keindahan. 